\title{
Insights into agricultural influences and weathering processes from major ion patters
}

Robert van Geldern ${ }^{1, *}$, Peter Schulte ${ }^{1,2}$, Michael Mader ${ }^{1}$, Alfons Baier ${ }^{1}$, Johannes A.C.

Barth $^{1}$, Tobias R. Juhlke ${ }^{1}$, Kern Lee ${ }^{1}$

${ }^{1}$ Friedrich-Alexander-University Erlangen-Nuremberg (FAU), Department of Geography and Geosciences, GeoZentrum Nordbayern, Schlossgarten 5, 91054 Erlangen, Germany

${ }^{2}$ Gehrenhagweg 6, CH-5420 Ehrendingen, Switzerland

*Corresponding author.

robert.van.geldern@fau.de. phone+49 9131 8522514. fax +49913129294.

This is the peer-reviewed version of the following article:

van Geldern, R., Schulte, P., Mader, M., Baier, A., Barth, J.A.C., Juhlke, T.R. and Lee, K. (2018):

Insights into agricultural influences and weathering processes from major ion patterns. -

Hydrological Processes, 32, 891-903,

which has been published in final form at http://dx.doi.org/10.1002/hyp.11461.

This article may be used for non-commercial purposes in accordance with Wiley Terms and

Conditions for Use of Self-Archived Versions. 


\section{ABSTRACT}

2 Karst areas and their catchments pose a great challenge for protection because fast conduit

3 flow results in low natural attenuation of anthropogenic contaminants. Studies of the

4 hydrochemistry of karst sources and river solutes are an important tool for securing and managing water resources. A study of the geochemical downriver evolution of the Wiesent

6 River and its tributaries, located in a typical karst terrain, revealed unexpected downstream

7 decreases of nitrate with maximum mean values of $30 \mathrm{mg} \mathrm{L}^{-1}$ at the source to minimum

8 values of $18 \mathrm{mg} \mathrm{L}^{-1}$ near the river mouth. This trend persisted over the length of the river

9 even though increased agricultural activities are evident in the downstream section of the

10 catchment. This pattern is caused by fertilizer inputs via diffusive and fast conduits flow from

11 karst lithology in the upstream area that may have reached the river's source even from

12 beyond the hydrological catchment boundaries. Further downstream, these influences became

13 diluted by tributary inputs that drain subcatchments dominated by claystone and sandstone

14 lithologies that increased potassium and sulfate concentrations. Our findings indicate that

15 bedrock geology remains the dominant control on the major ion chemistry of the Wiesent

16 River, and that agricultural influences are strongest near the headwaters despite increased

17 land-use further downstream, due to long-term storage and accumulation in karst aquifers.

18 This feature may not be unique to the Wiesent River system, as carbonates cover significant

19 portions of the Earth's surface and subsequent work in other river systems could establish 20 whether such patterns are ubiquitous worldwide.

22 Keywords

23 fertilizers, geochemistry, hydrology, karst, weathering, Wiesent River 


\section{INTRODUCTION}

Clean freshwater is essential to life. The most accessible form of freshwater is river and lake water, but it constitutes only a small fraction of less than $0.3 \%$ of the Earth's available total freshwater (Gleick, 1996). Groundwater is more abundant (30\%), but a less accessible form of freshwater that is primarily replenished by recharge from precipitation. All three surficial compartments of the hydrologic cycle - precipitation, rivers and lakes, and groundwater - are hydrologically interconnected. Studying the hydrochemistry of river solutes and suspended matter is therefore of importance for securing and managing this essential resource.

The factors controlling the chemical evolution of numerous of the world's largest river systems has been examined in several studies worldwide (Négrel et al., 1993; Yang et al., 1996; Gaillardet et al., 1997; Aucour et al., 1999; Galy and France-Lanord, 1999; Zhang et al., 1999; Kendall et al., 2001; Biggs et al., 2002; Hélie et al., 2002; Richey et al., 2002; Szramek et al., 2007; Chetelat et al., 2008; Raymond et al., 2008; Cartwright, 2010; Rosa et al., 2012; Voss et al., 2014). From their headwater catchments to their eventual confluence to the oceans, rivers act as a major global transportation network for water and solutes. Riverine continental fluxes of major elements, nutrients, and carbon phases were subsequently evaluated on a global scale (Gibbs, 1970; Meybeck, 1982; Meybeck, 1987; Gaillardet et al., 1999; Viers et al., 2009; Seitzinger et al., 2010; Aufdenkampe et al., 2011; Milliman and Farnsworth, 2011; Raymond et al., 2013; Marx et al., 2017a). Following these studies, numerous studies on smaller catchments and river systems were also carried out (e.g., Probst et al., 1992; Flintrop et al., 1996; Grosbois et al., 2000; Barth et al., 2003; Kanduč et al., 2007; Soulsby et al., 2007; Doctor et al., 2008; Stögbauer et al., 2008; Brunet et al., 2011; Kanduč et al., 2012; Kanduč et al., 2013; Zavadlav et al., 2013; Daesslé et al., 2016; Daesslé 
et al., 2017; Lee et al., 2017; Marx et al., 2017b), and most of these showed increasing conductivities and fluxes with closer proximity to confluences with larger river systems. This trend corresponds to increasing element loads further downstream and is usually related to increasing anthropogenic activities, including traffic infrastructure, settlements and agricultural practices in the downstream sections of catchments.

Karst areas and their rivers exhibit a great challenge to the protection of freshwater resources because fast conduit flow results in low natural attenuation of anthropogenic derived contaminants (Bakalowicz, 2005). These conduit systems make karst aquifers highly vulnerable to anthropogenic pollution, for example by nitrate $\left(\mathrm{NO}_{3}^{-}\right)$, because of the virtual absence of filter effects that are common in pore aquifers. Moreover, it is known that fertilizers can lower $\mathrm{pH}$ values and thus cause additional weathering that in turn should be particularly pronounced in karst that is susceptible to acidity changes (Semhi et al., 2000; Perrin et al., 2008; Gandois et al., 2011).

Here we present a small river system of $72.4 \mathrm{~km}$ length, the Wiesent River (Figure 1). Being dominated by karst lithology, it was first studied as an ideal natural laboratory for investigations of the aqueous carbon cycle in karst areas and its response to excessive carbon loss to the atmosphere, particularly in its source region (van Geldern et al., 2015). The catchment is situated in a dolomite and calcite-dominated terrain that trends towards shale and sandstone terrains in the lower reaches of the river (Figure 1). This allows for interpretations of spatial heterogeneity in river water chemistry, while sampling over a period of almost one year enabled temporal interpretations of seasonal variations in riverine solutes, carbon transport, $\mathrm{CO}_{2}$ evasion and associated changes in the carbon isotope distribution of dissolved inorganic carbon (DIC). 
The objectives of this study were to assess the spatial and temporal downriver evolution of major ion chemistry in a typical karst river with the initial hypothesis of a continuous increase of solutes along the flow path of the river. In particular, we investigated if such a trend could be observed in our data set. With this in mind, we evaluate relative influences of natural versus anthropogenic impacts, together with the role of groundwater contributions along the river course. This will advance the understanding of source-related inputs while providing information on the dilution of anthropogenic and weathering inputs in space and time. Regarding the high vulnerability of karst terrains by agricultural land use and anthropogenic pollution, this is of particular interest with regard to the ecological functioning of rivers with significant proportions of limestone in their catchment lithology.

\section{STUDY AREA}

The Wiesent River catchment with a total area of $1,040 \mathrm{~km}^{2}$ is located in southern Germany (Figure 1). The source of the Wiesent River is located in the northwest of the catchment area, at the hamlet of Steinfeld (our sampling site no. 1) at 445 meters above sea level (m.a.s.1.) (Figure 1). From this point, the river flows in a southeast to south direction. Near the town of Goessweinstein, the general flow direction changes westward until the river finally reaches the Regnitz River at 250 m.a.s.l. A map showing the digital elevation model (DEM) (Figure S1) is available from the Supplementary Material to this article. The total length of the Wiesent River is $72.4 \mathrm{~km}$ and the most important tributaries are the rivers Kainach, Truppach, Puettlach, Aufsess, Leinleiter, and Trubach (Figure 1). Two discharge gauges are located along the main river at the villages of Hollfeld and Muggendorf. They show averaged long-term discharge values of $1.04 \mathrm{~m}^{3} \mathrm{~s}^{-1}$ and $7.11 \mathrm{~m}^{3} \mathrm{~s}^{-1}$, respectively (LfU, 2014). 
The study area is located in a karst region with lithologies of calcites and dolomites that are occasionally interbedded with marly layers. These sediments form the Franconian Jura uplands, which belong to the Franconian Alb that is part of the South German

Scarplands. Overall, late Jurassic carbonates cover the majority ( $\sim 67 \%)$ of the catchment area

(Figure 1). These comprise a limestone sequence of up to $200 \mathrm{~m}$ thickness that is in part dolomitized, and forms a typical karst landscape of the area with incised rivers and other dry valleys, dolines and caverns (Figure 2). This carbonate sequence is overlain by relict patches of Late Cretaceous sandstone with interbedded marl and shale layers. consequence, lower Jurassic and Late Triassic sandstones and claystones that underlie the

104 thick Late Jurassic carbonate succession crop out in the south-western part of the catchment (Figure 2). Additional sandstone and claystone lithologies of the same Triassic sequence also appear in the eastern part of the main basin, in subcatchments of the tributaries Truppach and

107 Puettlach. Here, the sandstones and claystones were lifted to the surface along a northwest108 southeast striking fault.

109 The vegetation in the south-western part of the catchment is characterized by broad-

110 leaved forest dominated by beeches and scattered small fruit orchards. Coniferous trees

111 largely forest the northern and central parts of the catchment, while the eastern regions consist

112 of grassland pastures. Numerous small villages are present in the basin and, especially in the 113 downstream part of the catchment, agriculture and tourism play an important role in land use

114 (Figure 3). In particular, farming activities along the river course were expected to

115 significantly influence the water chemistry. For information on land cover and land use along 116 the river course refer to Figure 3 and also the high resolution local Riparian Zone (RZ) and 
117 Pan-European CORINE Land Cover (CLC) maps of the Copernicus Land Monitoring

118 Service $^{1}$ (part of the European Union's Earth Observation Programme).

\section{METHODS}

Eight locations along the Wiesent River main course (sites 1 to 8 in Figure 1; exact Global Positioning System coordinates of sampling locations are available in the Supplementary Material) were sampled during eight field campaigns in February, March, April, May, July, August, September, and November 2010 in order to encompass all seasons. Additionally, the six most important tributaries were sampled (sites 9 to 14 in Figure 1).

These tributaries were included in the regular sampling interval in April 2010 and sampled during the last six of the eight sampling campaigns. All tributaries were sampled near their confluences with the Wiesent River, with water samples collected manually from the middle of the rivers. All bottles were rinsed several times with sample water before filling. Samples destined for major ion analyses were filled without headspace in double closure $100 \mathrm{~mL}$ highdensity polyethylene bottles with an inner stopper (product item LR100-2, Gosselin SAS, Borre, France). These were then stored in the dark and at $4^{\circ} \mathrm{C}$ until analysis. Measurements of temperature, $\mathrm{pH}$, electrical conductivity (EC), and dissolved oxygen (DO) were conducted in the field by a multi-parameter instrument (WTW Multi 350i, WTW $\mathrm{GmbH}$, Weilheim, Germany) during all field campaigns. All probes were calibrated prior to each field campaign. The $\mathrm{pH}$ and conductivity probes used built-in automatic temperature compensation functions, and temperature precision is quoted as $\pm 0.1^{\circ} \mathrm{C}$ by the manufacturer. Conductivity values were referenced to $25^{\circ} \mathrm{C}$ by a non-linear correction function (nLF) for

\footnotetext{
${ }^{1}$ https://land.copernicus.eu (last accessed 17 January 2018)
} 
natural waters. For $\mathrm{pH}$ measurements precision was better than $\pm 0.05 \mathrm{pH}$ units $(1 \sigma)$ and for conductivity determinations it was better than $\pm 5 \mu \mathrm{S} \mathrm{cm}^{-1}$. Dissolved oxygen was determined by a galvanic sensor and automatically corrected for ambient air pressure by a built-in pressure sensor.

Total alkalinity (TA) was determined from $100 \mathrm{~mL}$ water samples directly in the field by a Hach Digital Titrator (Model 1690001, Hach Company, Loveland, CO, USA). The titration endpoint was determined by color changes in a $\mathrm{pH}$ indicator (bromcresol greenmethyl red). At a $\mathrm{pH}<9$, hydroxide $\left(\mathrm{OH}^{-}\right)$does not contribute to TA at an appreciable concentration and other TA contributing species $\left(\mathrm{BOH}_{4}^{-}, \mathrm{H}_{3} \mathrm{SiO}_{4}^{-}\right)$can be regarded as negligible in the waters examined by this study. Therefore, TA essentially contains only carbonic alkalinity and the titration value was used for the calculation of carbonate species concentrations, which is mainly hydrogencarbonate $\left(\mathrm{HCO}_{3}^{-}\right)$in the observed $\mathrm{pH}$ range (see Verma et al., 2015).

$$
\text { Cations }\left(\mathrm{Na}^{+}, \mathrm{K}^{+}, \mathrm{Li}^{+}, \mathrm{NH}_{4}^{+}, \mathrm{Ca}^{2+}, \mathrm{Mg}^{2+}\right) \text { and anions }\left(\mathrm{F}^{-}, \mathrm{Cl}^{-}, \mathrm{NO}_{3}^{-}, \mathrm{NO}_{2}^{-}, \mathrm{SO}_{4}^{2-}\right. \text {, }
$$

$\mathrm{PO}_{4}^{3-}$ ) were determined by ion chromatography (ICS 2000, Thermo Dionex, Sunnyvale, CA, USA). Prior to ion chromatographic analyses, samples were filtered with $0.45 \mu \mathrm{m}$ disk filters, which were flushed with sample before the autosampler vials were filled. Limit of quantification (LOQ) for major ions was $0.1 \mathrm{mg} \mathrm{L}^{-1}$ with a typical precision of $<5 \%(1 \sigma)$ relative standard deviation (RSD) based on the repeated analysis of two control standards treated as unknowns in the lower and upper calibration range. Typical charge errors derived from equivalent concentrations of ion chromatography and field titration data were between 5 and $12 \%$. 
160

161

162

163

164

\section{RESULTS}

Major ion concentrations $\left(\mathrm{Na}^{+}, \mathrm{K}^{+}, \mathrm{Ca}^{2+}, \mathrm{Mg}^{2+}, \mathrm{HCO}_{3}^{-}, \mathrm{Cl}^{-}, \mathrm{NO}_{3}^{-}, \mathrm{SO}_{4}^{2-}\right)$ and measured physico-chemical in-situ parameters (temperature, electric conductivity) along the river course are shown in Figure 4. The Supporting Information to this article contains detailed analytical data of the Wiesent River main course (Table S1) and its tributaries (Table S2). The Supporting Material to this article is accessible through the journals website and is additionally archived in the World Data Center PANGAEA ${ }^{2}$ for long-term storage and free access. In addition to the ion concentrations and field parameters presented in this article, the stable isotope geochemistry $\left(\delta^{18} \mathrm{O}_{\mathrm{H}_{2} \mathrm{O}}, \delta^{2} \mathrm{H}_{\mathrm{H}_{2} \mathrm{O}}\right.$, and $\left.\delta^{13} \mathrm{C}_{\text {DIC }}\right)$ of the Wiesent River was also measured and is described in van Geldern et al. (2015).

The water temperature at the Wiesent River's source was stable during all seasons with an average temperature of $(9.0 \pm 0.2){ }^{\circ} \mathrm{C}$ (arithmetic average $\left.\pm 1 \sigma\right)$. Other parameters, such as $\mathrm{pH}$ or conductivity also showed very stable values at the source independent of the season (Figure 4, Table S1). Along the Wiesent River's course, the water temperature correlated with seasonal air temperatures with cooler temperatures in February and March and warmer ones in July and August. Electrical conductivity generally decreased over the first 30 $\mathrm{km}$ from a value of $(728 \pm 11) \mu \mathrm{S} / \mathrm{cm}$ at the source to values between 550 to $650 \mu \mathrm{S} / \mathrm{cm}$. After $30 \mathrm{~km}$, the values remained relatively stable and no significant changes were observed over the second half of the river course. Lowest conductivity values were observed during November, March, and August sampling campaigns conducted shortly after precipitation

\footnotetext{
${ }^{2}$ https://doi.pangaea.de/10.1594/PANGAEA.885224
} 
180 events. In contrast, the highest conductivity values were measured in February after a dry

181 period with snow covered landscape and low discharge values. Precipitation and discharge

182 data for the sampling campaigns are published in van Geldern et al. (2015).

183 Calcium $\left(\mathrm{Ca}^{2+}\right)$, showed the highest concentrations amongst all cations, followed by

184 magnesium $\left(\mathrm{Mg}^{2+}\right)$, sodium $\left(\mathrm{Na}^{+}\right)$, and potassium $\left(\mathrm{K}^{+}\right)$. Lithium $\left(\mathrm{Li}^{+}\right)$concentrations were

185 always below LOQ $\left(<0.1 \mathrm{mg} \mathrm{L}^{-1}\right)$. Ammonium $\left(\mathrm{NH}_{4}^{+}\right)$was detected in only two samples

186 during February, with values of 0.11 and $0.28 \mathrm{mg} \mathrm{L}^{-1}$, and was not detectable (below limit of

187 detection, LOD) in all others. In contrast to most other parameters, $\mathrm{Ca}^{2+}$ and $\mathrm{Mg}^{2+}$

188 concentrations showed little variability at the source during the various sampling campaigns,

189 although their general downstream patterns were almost identical for all sampling campaigns.

$190 \mathrm{Ca}^{2+}$ exhibited a range of 90 to $145 \mathrm{mg} \mathrm{L}^{-1}$, whereas $\mathrm{Mg}^{2+}$ concentrations ranged between 15

191 and $45 \mathrm{mg} \mathrm{L}^{-1}$ (Figure 4).

192 The concentration pattern of $\mathrm{Ca}^{2+}$ showed an initial decrease between the source and

193 sampling site 2 (Wiesentfels; Figure 1), whereas $\mathrm{Mg}^{2+}$ increased within the same direction.

194 Further downstream, $\mathrm{Ca}^{2+}$ concentrations remained fairly stable and ranged between 105 and

$195130 \mathrm{mg} \mathrm{L}^{-1}$, with exception of the November campaign that was characterized by lower

196 values further downstream. After the initial rise, $\mathrm{Mg}^{2+}$ concentrations tended to decrease until

197 sampling site 4 (Waischenfeld) and showed only minor variations thereafter. In particular,

$198 \mathrm{Mg}^{2+}$ concentrations showed a clear correlation with corresponding EC values for different

199 sampling campaigns, which in turn were correlated with precipitation events and resulting

200 increased discharge values (data shown in van Geldern et al., 2015). This trend was also

201 obvious to a lesser extent for $\mathrm{Ca}^{2+}$, especially during the November campaign. 
$202 \mathrm{Na}^{+}$concentrations ranged from 8 to $15 \mathrm{mg} \mathrm{L}^{-1}$, stabilizing at a value of $(11.2 \pm 0.6) \mathrm{mg} \mathrm{L}^{-1}$ at 203 the source followed by a slight initial rise. Values declined further downstream to 204 concentrations of about $8 \mathrm{mg} \mathrm{L}^{-1}$ at the lower river course. $\mathrm{K}^{+}$concentrations increased from $(1.04 \pm 0.24) \mathrm{mg} \mathrm{L}^{-1}$ at the source to values of around $2.0 \mathrm{mg} \mathrm{L}^{-1}$ downriver. Maximum values of $3.5 \mathrm{mg} \mathrm{L}^{-1}$ were recorded during the

207 November sampling campaign at site 4 (Waischenfeld) and also at locations further 208 downstream. Note that during this campaign most other parameters, for example $\mathrm{Ca}^{2+}$ and $209 \mathrm{Mg}^{2+}$ concentrations or EC, showed lower values. This trend was most likely related to heavy 210 rains occurring prior to that campaign.

212 source was hydrogencarbonate $\left(\mathrm{HCO}_{3}^{-}\right)$, nitrate $\left(\mathrm{NO}_{3}^{-}\right)$, chloride $\left(\mathrm{Cl}^{-}\right)$, and sulfate $\left(\mathrm{SO}_{4}^{2-}\right)$

213 with concentrations of $(357 \pm 7),(29.6 \pm 2.7),(22.7 \pm 1.6)$, and $(15.8 \pm 1.5) \mathrm{mg} \mathrm{L}^{-1}$,

214 respectively. Interestingly, the downstream behavior revealed different patterns for these 215 anions. $\mathrm{NO}_{3}^{-}$showed an almost linear monotonic decline over the river course to $(17.6 \pm 1.6)$ $216 \mathrm{mg} \mathrm{L}^{-1}$ at the final sampling site 8 (Kirchehrenbach) and $\mathrm{HCO}_{3}^{-}$decreased to an average of $217(307 \pm 22) \mathrm{mg} \mathrm{L}^{-1}$. The lowest $\mathrm{HCO}_{3}^{-}$values were measured along the lower course during 218 the November sampling campaign. A pronounced decrease was observed after the confluence 219 with the tributary Truppach (10), whereby $\mathrm{HCO}_{3}^{-}$concentrations dropped below $250 \mathrm{mg} \mathrm{L}^{-1}$ 220 in November. The minimum concentration of $228 \mathrm{mg} \mathrm{L}^{-1}$ was recorded at Goessweinstein (6), 221 located downstream of the Puettlach (12) tributary. During other campaigns, $\mathrm{HCO}_{3}^{-}$ 222 concentrations along the lower course (site 4 and downstream), ranged from 340 to $280 \mathrm{mg} \mathrm{L}^{-}$ $22{ }^{1}$ (Figure 4). 
226 values. $\mathrm{Cl}^{-}$concentrations along the lower course ranged from 15 to $25 \mathrm{mg} \mathrm{L}^{-1}$ (Figure 4). In 227 contrast, $\mathrm{SO}_{4}^{2-}$ behaved similar to $\mathrm{K}^{+}$with a continuous increase along the Wiesent River up 228 to values of 20 to $30 \mathrm{mg} \mathrm{L}^{-1}$ near the mouth of the Wiesent at its confluence with the Regnitz.

229 A larger variability of $\mathrm{SO}_{4}^{2-}$ could be observed downstream of sampling site 4

230 (Waischenfeld). Here, maximum concentrations of up to $42 \mathrm{mg} \mathrm{L}^{-1}$ were recorded during the 231 November sampling campaign. However, an exception from this behavior was observed in 232 February, when the second highest $\mathrm{SO}_{4}^{2-}$ concentrations were measured at the middle and 233 lower course, while the downstream conductivity curve showed maximum values (Figure 4). Low concentrations for fluoride $\left(\mathrm{F}^{-}\right)$and phosphate $\left(\mathrm{PO}_{4}^{3-}\right)$ above LOD were detected 235 in 12 and 11 out of 64 analyses, respectively (cf. Table S1 in Suppl. Material). When 236 detected, typical concentrations of $\mathrm{F}^{-}$and $\mathrm{PO}_{4}^{3-}$ were below $0.3 \mathrm{mg} \mathrm{L}^{-1}$ and never exceeded $2370.5 \mathrm{mg} \mathrm{L}^{-1}$. Nitrite $\left(\mathrm{NO}_{2}^{-}\right)$was not detected in any of the sampling campaigns in the main 238 stem of the Wiesent River (cf. Suppl. Material).

239 The tributary and Wiesent River samples are characterized by their major ions in a 240 Piper diagram (Piper, 1944) (Figure 5). Here the tributaries are marked with their numbers in 241 brackets according to Figure 1. The tributaries Kainach (9), Aufsess (11), and Trubach (14) 242 were largely similar to the water chemistry of the main stem of the Wiesent River. The only 243 exception was the Leinleiter tributary (13) with its lower $\mathrm{Mg}^{2+}$ concentrations, but most other 244 major ion concentrations were similar to those observed in the main river. Note that the two 245 eastern tributaries Truppach (10) and Puettlach (12) plot differently in Figure 5. For instance, $246 \mathrm{Mg}^{2+}$ concentrations were below $12 \mathrm{mg} \mathrm{L}^{-1}$ in all samples taken from the Truppach (10) 247 tributary. Morover, both the Truppach (10) and the Puettlach (12) were characterized by lower $248 \mathrm{HCO}_{3}^{-}$, increased $\mathrm{K}^{+}$, and high $\mathrm{SO}_{4}^{2-}$ concentrations. These patterns were also seen in the 
249 middle and lower course of the Wiesent River. This was particularly evident after

250 precipitation events, for instance during November. Finally, low concentrations of $\mathrm{PO}_{4}^{3-}(0.11$

251 to $0.72 \mathrm{mg} \mathrm{L}^{-1}$ ) were found during all campaigns in the Truppach (10) and Puettlach (12), but 252 not in the other tributaries (Table S2).

\section{DISCUSSION}

\section{Geological and anthropogenic controls}

255 The downstream evolution of the parameters discussed above indicates that

256 groundwater is one of the major contributors to the Wiesent River and its tributaries (Figure

257 4). The expectation is that groundwater infiltration to the river occurs primarily by the piston-

258 flow effect, which is then modified along the river course by mixing with tributary-derived

259 water and minor contributions from surface runoff or soil water. Subsurface groundwater

260 contributions to the river and its tributaries are not expected to significantly modify the water

261 chemistry of the main course, as groundwater along the length of the Wiesent River and from

262 most subcatchments originates from the same large deep karst aquifer that feeds the Wiesent

263 River's source (Figure 1). For subcatchments with large proportions of non-carbonate

264 lithology this situation may differ. Increased surface runoff is normally observed during

265 snowmelt and more intensive precipitation events (Bukaveckas, 2010). This would

266 particularly hold true for precipitation in tributaries that drain poorly permeable sediments,

267 such as in the eastern part of the catchment (Truppach (10) and Puettlach (12)). In these

268 subcatchments, which are dominated by clay and sandstone-claystone lithologies, overland

269 flow generation should play a more important role than in permeable karst lithology with its

270 fast infiltration rates (Bakalowicz, 2005; Ford and Williams, 2007). The rapid delivery of

271 low-mineralized rain water via overland flow and shallow soil flowpaths results in lower 
272 solute concentrations during increased discharge (Allan and Castillo, 2007; Bukaveckas, 273 2010). Mixing of these tributary waters with the main river stem is the most important process 274 affecting the dilution of total dissolved solids (TDS), as indicated by lower EC values. When tributaries are chemically different as compared to the main stem of the Wiesent 276 River, their influences are expected to be obvious. For instance, lower $\mathrm{Mg}^{2+}$ concentrations in 277 the Truppach (10; Table S2) likely caused the pronounced drop in $\mathrm{Mg}^{2+}$ after sampling sites 3 278 (Hollfeld) in the Wiesent River (Figure 4). This decline was even more pronounced during 279 periods of low conductivity following precipitation events.

On the other hand, contributions of tributaries that drain a similar lithology as the

281 Wiesent River are harder to detect by changes in aquatic chemistry and natural environmental 282 tracers (Clark and Fritz, 1997; Cook and Herczeg, 2000). For instance, near the catchment 283 outlet, the lithology along the Wiesent River valley changes from carbonate rocks to 284 claystone. The formation is known as the Feuerletten Formation from the Late Trassic period. 285 With exception of small changes in $\mathrm{Ca}^{2+}, \mathrm{Mg}^{2+}$, and $\mathrm{Na}^{+}$, the measured parameters did not 286 respond to this prominent change in riverbed lithology. This indicates that groundwater 287 contributions at the final river stretch likely become less important due to the less permeable 288 nature of the underlying thick claystone formation. 290 along the river course, this value varies only slightly between 81 and $88 \%$. This shows that 291 carbonate weathering of calcite $\left(\mathrm{CaCO}_{3}\right)$ and dolomite $\left(\mathrm{CaMg}\left(\mathrm{CO}_{3}\right)_{2}\right)$ mainly accounts for the 292 high concentrations of these three ions. The stoichiometry of carbonate weathering reactions 293 demands that carbonate-derived $\mathrm{Ca}^{2+}$ and $\mathrm{Mg}^{2+}$ should be equal to that of $\mathrm{HCO}_{3}^{-}$when 294 expressed in (milli)equivalents per liter $\left(\mathrm{meq} \mathrm{L}^{-1}\right)$. Such a plot of $\left(\mathrm{Ca}^{2+}+\mathrm{Mg}^{2+}\right)$ over $\mathrm{HCO}_{3}^{-}$ 295 concentrations reveals a general excess of $\mathrm{Ca}^{2+}$ and $\mathrm{Mg}^{2+}$ over $\mathrm{HCO}_{3}^{-}$(Figure 6A). This 
excess of cations is partially balanced by $\mathrm{Cl}^{-}, \mathrm{SO}_{4}^{2-}$, and $\mathrm{NO}_{3}^{-}$, and suggests that fractions of

$297 \mathrm{Ca}^{2+}$ or $\mathrm{Mg}^{2+}$ concentrations in the watershed were not exclusively derived from carbonate 298 weathering (Meybeck, 1987). Other potential natural sources of $\mathrm{Ca}^{2+}$ are gypsum or the 299 silicate weathering of Ca-bearing minerals such as anorthite (Berner et al., 1983; Meybeck, 300 1987). However, both minerals are of minor importance in the Jurassic limestone formations 301 and are therefore unlikely candidates for leaching $\mathrm{Ca}^{2+}$ and $\mathrm{Mg}^{2+}$. nutrient mineral fertilizers that contain $\mathrm{Ca}^{2+}$ or $\mathrm{Mg}^{2+}$-bearing compounds, such as for example magnesium ammonium phosphate (MAP) (EPA, 1999). This should also correlate with other solutes that are typically derived from these fertilizers, such as $\mathrm{NO}_{3}^{-}$. Further anthropogenic sources that may exist in the watershed include organic fertilizers or domestic sewage. Typical anthropogenic compounds are $\mathrm{PO}_{4}^{3-}, \mathrm{SO}_{4}^{2-}$ and nitrogen $(\mathrm{N})$ compounds $\left(\mathrm{NO}_{3}^{-}, \mathrm{NO}_{2}^{-}\right.$, $308 \mathrm{NH}_{4}^{+}$) sourced from manure and mineral fertilizers. In particular, elevated $\mathrm{NO}_{3}^{-}$ concentrations are often related to the use of such fertilizers. During this study, the highest concentrations of $\mathrm{NO}_{3}^{-}$were found at the source of the Wiesent River with a consistent value

311 of $(29.6 \pm 2.7) \mathrm{mg} \mathrm{L}^{-1}$. This stability of $\mathrm{NO}_{3}^{-}$concentrations at the source suggests that $\mathrm{NO}_{3}^{-}$ 312 may have been continuously transferred into the feeding karst aquifer, which acted as a large reservoir (see also van Geldern et al., 2015 for additional information). With respect to the 314 common dual-flow concept for groundwater flow in karst aquifers (Atkinson, 1977; White, 315 1988; Ford and Williams, 1989; Kiraly, 1998; Ford and Williams, 2007; Goldscheider and 316 Drew, 2007), the observed pattern at the Wiesent source reflects the diffusive flow component 317 through fractures and pores. In contrast to the faster reacting conduit flow system that 318 transports water along pipe-like conduits and cave stream channel, the diffusive flow reflects $319 \mathrm{NO}_{3}^{-}$average values and long-term-trends (Huebsch et al., 2014). Subsequently, $\mathrm{NO}_{3}^{-}$likely 
320 has accumulated over decades in the deep karst aquifer and seasonal variations became 321 negligible.

This supports the interpretation that the observed excess of $\mathrm{Ca}^{2+}$ and $\mathrm{Mg}^{2+}$ is a result of

323 long-term anthropogenic influences on the groundwater, particularly at the Wiesent River

324 spring and the upper reaches. It is therefore indicative of influences from farming activities in

325 the upper part of the catchment. The Wiesent River has its source in a rural, largely natural 326 region where forests and grassland dominate large portions of the catchment and industry 327 does not play a significant role (Figure 3). Therefore, anthropogenic signals in river water 328 chemistry were expected to be minimal, with inorganic aquatic chemistry mainly mirroring 329 weathering processes or changes in lithology. However, particularly in karst systems, virtually 330 unfiltered anthropogenic influences may directly enter the source and the river via the fast 331 conduit and the slower diffusive flow systems (Atkinson, 1977; Ford and Williams, 2007). 332 As opposed to the expected trend of increasing $\mathrm{NO}_{3}^{-}$concentrations further

333 downstream where agriculture and urbanization is more prevalent, a contrary pattern was 334 observed: $\mathrm{NO}_{3}^{-}$concentrations were found to be highest at the source of the Wiesent River 335 (see discussion above) and subsequently decreased with distance from the headwaters during 336 all sampling periods (Figure 4). This pattern is further suggestive of the long-term influences 337 of agricultural land use on groundwater, particularly in the upstream section of the watershed. 338 Even though agricultural activities are also prevalent in the downstream part of the catchment, 339 their associated $\mathrm{NO}_{3}^{-}$releases may not reach the river as quickly because the lithology 340 contains a high proportion of fine sandstones and shales (Figure 1) that slows or hampers 341 groundwater-related transport to the river. During large precipitation events, solutes can be 342 mobilized and transported to the river course quickly by overland flow and shallow soil flow 343 paths, but short transit times along these paths limit the interaction between low-mineralized 
344 rainwater and soil. High discharge is therefore often characterized by lower concentrations of 345 dissolved substances (Bukaveckas, 2010). Such patterns can be identified in our data set, for 346 example during the sampling campaigns in March, August, and November (Figure 4). These 347 sampling campaigns were conducted shortly after precipitation events (see above) and are 348 characterized by low EC values.

As for other anthropogenic parameters, road salt and domestic sewage are a primary 350 source of $\mathrm{Na}^{+}$and especially $\mathrm{Cl}^{-}$(Liu et al., 2008; Sun et al., 2014) since natural sources, 351 such as evaporite dissolution or atmospheric sea salt deposition (Meybeck, 1987) is unlikely 352 in the study area. Increases in $\mathrm{Na}^{+}$or $\mathrm{Cl}^{-}$concentrations were not observed at the source 353 during colder periods. This could indicate that either they were dampened in the large feeding 354 karst reservoir or that road salting had only a minor influence on the river water chemistry. 355 Since both $\mathrm{Cl}^{-}$and $\mathrm{Na}^{+}$showed no distinct seasonality over the entire course or the river, a 356 pronounced influence of this source is likely minor in this catchment. It is more likely that 357 these elements reach the river via agricultural activities that are more dominant in the source 358 region, as previously stated. At this juncture, it is unclear why both $\mathrm{Cl}^{-}$and $\mathrm{Na}^{+}$show 359 significant increases from the spring to the second sampling station (site 2, Wiesentfels), 360 although this trend may be related to the presence of point sources such as sewage discharge 361 or livestock waste from farms (Mullaney et al., 2009; Kelly et al., 2012).

$362 \mathrm{Cl}^{-}$was also found to be in excess of $\mathrm{Na}^{+}$and $\mathrm{K}^{+}$and their inclusion in a cation-anion 363 plot does not follow a 1:1 ratio (Figure 6B). The $\mathrm{Cl}^{-}$excess could in part be balanced by 364 excess $\mathrm{Ca}^{2+}$ and $\mathrm{Mg}^{2+}$ that does not account for carbonate weathering. When assuming that 365 this cation excess stems from fertilizer use in the upstream part of the catchment, it supports 366 the hypothesis that fertilizers are more pronounced in upstream river sections and may have 367 entered the river via diffusive flow in the present karst system (Huebsch et al., 2014). 
369 also have contributed to the fertilizer load of the river. However, both $\mathrm{K}^{+}$and $\mathrm{SO}_{4}^{2-}$ exhibit

370 their lowest values in the source region and show increases further downstream (Figure 4). At

371 a glance, this pattern does not appear to support the hypothesis of more pronounced fertilizer

372 input in the upstream part of the catchment. However, it is possible that both ions enter the 373 river as a result of fertilizer transport in the upstream, karst-dominated section of the

374 catchment. The baseline values at the source may then have increased further downstream 375 mainly as a result of $\mathrm{K}^{+}$and $\mathrm{SO}_{4}^{2-}$ released from weathering processes in the clay-rich shale 376 formations in the eastern subcatchments, and discharged into the main river stem via 377 tributaries. These and other mechanisms of tributary influences are discussed below.

\section{Downstream geochemical evolution}

379 After setting of the initial values for physico-chemical parameters at the source, many 380 parameters show changes along the river course. This may be either related to processes that 381 occur within the main river itself such as seasonal temperature changes, or is due to the inflow 382 and mixing of waters from different sources (Allan and Castillo, 2007; Likens, 2010). 383 An important question in river research is the interaction between river water and 384 surface water within the hyporheic and riparian zones along the river course (Krause et al., 385 2009; Kanduč et al., 2012; Kanduč et al., 2013; Krause et al., 2014). Depending on the 386 hydraulic system, the river can lose water to groundwater via outflow through the riverbed 387 (Winter et al., 1998; Engelhardt et al., 2014). This situation is denoted as a losing stream. 388 Alternatively, water from the riparian zone can feed the river, which is denoted as a gaining 389 steam. Different environmental tracers, for example temperature, stable isotopes, or 390 wastewater-related pollutants, have been used to investigate these interactions in detail 391 (Engelhardt et al., 2014; Fox et al., 2016). Furthermore, tributaries with differing water 
392 chemistry that mix with the main river course can also induce changes in water chemistry 393 when these differences and fluxes are large enough to cause a measurable shift (Perrin et al., 394 2007; Torres et al., 2017).

The downstream temperature development of the Wiesent River varies seasonally,

396 with higher temperatures in summer and lower temperatures in winter (Figure 4).

397 Groundwater seeps would shift the warm or cold temperature curve locally towards the 398 average groundwater temperature of about $9^{\circ} \mathrm{C}$ for this region. However, the spatial 399 resolution along the river is not detailed enough to detect point-source groundwater inflow. 400 This is because groundwater temperature can be expected to adjust quickly to the river water 401 temperature. Minor groundwater contributions would therefore only be detectable close to the 402 point of inflow. However, a steady and spatially ubiquitous groundwater inflow along the entire river course would likely dampen seasonal changes within the river. Such trends could only be observed at the source and for the remainder of the river length it is more likely that groundwater contributions are of minor importance.

A closer examination of the downstream curves showed a notable increase in $\mathrm{Mg}^{2+}$ 407 concentrations of 7 to $13 \mathrm{mg} \mathrm{L}^{-1}$ from the source to sampling site 2 (Wiesentfels; Figure 4). A 408 larger fraction of dolomite weathering might have increased the portion of $\mathrm{Mg}^{2+}$ over $\mathrm{Ca}^{2+}$. 409 However, this shift was also correlated with increases of $\mathrm{Na}^{+}$and $\mathrm{Cl}^{-}$(Figure 4). To a large 410 degree, the latter elements are likely of anthropogenic origin (Jiang et al., 2009) and this 411 coincidence suggests that the $\mathrm{Mg}^{2+}$ increase has a potential (but as yet unidentified) 412 anthropogenic component. This is supported by the fact that the increase in $\mathrm{Cl}^{-}$was larger 413 than the corresponding increase in $\mathrm{Na}^{+}, \mathrm{so}^{-}$could have contributed to the buffering of the $414 \mathrm{Mg}^{2+}$ increase. However, even when accounting for $\mathrm{Cl}^{-}$, a negative charge deficit persisted 415 and $\mathrm{Mg}^{2+}$ must have been additionally balanced by other anions. As no other major anions 
$416\left(\mathrm{SO}_{4}^{2-}, \mathrm{NO}_{3}^{-}\right)$showed a corresponding increase, the surplus of $\mathrm{Mg}^{2+}$ is most likely buffered by 417 organic compounds that were not measured in this study.

418 The downstream evolution of $\mathrm{K}^{+}$and $\mathrm{SO}_{4}^{2-}$ in the Wiesent River showed opposing 419 patterns as compared to the other major ions along the course (see above). Both ion 420 concentrations gradually increased downstream, whereas other major ion concentrations 421 decreased most likely due to dilution effects by the tributaries Truppach (10) and Puettlach 422 (12), which drain a different lithology. Their lithology is dominated by claystone and 423 sandstone (see Figure 1) and increased concentrations of $\mathrm{K}^{+}$and $\mathrm{SO}_{4}^{2-}$ were observed in these 424 two eastern tributaries (Table S2 in Supplementary Material). A potential anthropogenic 425 source are fertilizers because potassium $(\mathrm{K})$ is, together with nitrogen $(\mathrm{N})$ and phosphorous $426(\mathrm{P})$, a primary nutrient (macronutrient) and component in many commercial NPK fertilizers 427 (EPA, 1999). Potassium Sulfate $\left(\mathrm{K}_{2} \mathrm{SO}_{4}\right)$ is a common inorganic fertilizer that is often used in 428 fruit orchards. $\mathrm{K}^{+}$and $\mathrm{SO}_{4}^{2-}$ show a fairly strong correlation in the two subcatchments 429 (Pearson correlation coefficient $r=0.69, p=0.012$ for a two tailed test; statistically 430 significant at the $>95 \%$ level) but only about one-tenth of the $\mathrm{SO}_{4}^{2-}$ is balanced by $\mathrm{K}^{+}$in this 431 scenario. Other common K-bearing fertilizers are $\mathrm{KCl}, \mathrm{KNO}_{3}$, and the crude potassium salts 432 sylvinite and kainite. Alternatively, one plausible natural source for $\mathrm{K}^{+}$is weathering of orthoclase and other 434 K-bearing silicate minerals in the clastic sediments (Wollast and Mackenzie, 1983; Struyf et 435 al., 2009). As a result of these weathering processes, a larger amount of $\mathrm{K}^{+}$may have been 436 transported into the Wiesent River. The higher $\mathrm{SO}_{4}^{2-}$ concentrations could have been caused by the dissolution of gypsum 438 and/or weathering of pyrite (Sun et al., 2014). Both minerals are present in the Lower and 439 Middle Jurrasic formations (Krumbeck, 1956; Schröder, 1968) and pyrite is especially 
440 abundant in the thick claystone sequence of the 'Amaltheenton' and 'Opalinuston' formations 441 that cover large areas of the eastern subcatchments (Wippern, 1955). The principles of pyrite 442 oxidation follow a sequence of reactions that involve microbiologically-mediated and oxic 443 decomposition of pyrite followed by an anoxic decomposition of pyrite by ferric iron

444 (Lowson, 1982; Evangelou, 1995). The overall stoichiometry is represented by:

$$
2 \mathrm{FeS}_{2}+7 \mathrm{O}_{2}+2 \mathrm{H}_{2} \mathrm{O} \rightarrow 2 \mathrm{Fe}^{+}+4 \mathrm{SO}_{4}^{2-}+4 \mathrm{H}^{+}
$$

445 Pyrite weathering reactions release acidity and result in low $\mathrm{pH}$ values. However, lower $\mathrm{pH}$ 446 values were neither observed in the Wiesent nor in any of the tributaries (cf. Tables S1 and S2 447 and van Geldern et al., 2015). This absence of an expected $\mathrm{pH}$ decrease could be explained 448 by the presence of up to $10 \%$ carbonates in the claystones (Schröder, 1968). This means that 449 acidity derived from equation (1) could become directly neutralized by reaction with 450 carbonates. Unexpectedly higher concentrations of $\mathrm{K}^{+}$and $\mathrm{SO}_{4}^{2-}$ in the Truppach (10) and 452 Puettlach (12) tributaries was observed in November: samples from this month showed 453 increased concentrations of $\mathrm{K}^{+}$and $\mathrm{SO}_{4}^{2-}$ that were also found in the middle and lower 454 reaches of the Wiesent River, downstream of the Truppach (10) and Puettlach (12) 455 confluences (Figure 4). In contrast, most other ions (e.g., $\mathrm{Ca}^{2+}$ or $\mathrm{Mg}^{2+}$ ) were diluted. This 456 dilution can be attributed to increased fluxes of low-mineralized surface runoff following a 457 heavier period of rainfall in November (see van Geldern et al., 2015 for precipitation and 458 discharge data). Surface runoff was also expected to dilute concentrations of $\mathrm{K}^{+}$and $\mathrm{SO}_{4}^{2-}$. 459 However, the data suggest that both ions were mobilized within the soil zone and flushed out, 460 with increased concentrations along the eastern tributaries into the Wiesent River during 461 precipitation events (van Geldern et al., 2015). 
462

463

464

465

466

467

468

469

470

471

472

473

474

475

476

477

478

479

480

481

482

483

484

\section{CONCLUSIONS}

The Wiesent River has an unusual chemical downriver evolution, particularly for solutes that are often derived from agricultural fertilizers. While increased anthropogenic activities normally occur in the downriver sections of the catchment, an unexpectedly stronger fertilizer-derived signal (particularly $\mathrm{NO}_{3}^{-}$) was discerned in its upstream area. These agricultural inputs may have been introduced through fast conduit and fracture flow in the karst lithology of the upstream catchment. Agricultural influences may even stem from beyond the catchment surface water boundaries. After leaving the source, these inputs became diluted further downstream, specifically via tributaries that were not sourced from carbonate lithologies. While $\mathrm{Ca}^{2+}, \mathrm{HCO}_{3}^{-}$and $\mathrm{NO}_{3}^{-}$decreased over the course of the river, we found increases of $\mathrm{K}^{+}$and $\mathrm{SO}_{4}^{2-}$ in the downstream section that is more influenced by clay lithologies. This enables a division of the river into two sections: an upstream part that is dominated by karst and receives strong fertilizer inputs, and a downstream section that receives less groundwater inputs but is subject to increased contributions by tributaries that drain sandstone and shale lithologies. This highlights the importance of including tributaries in river studies.

This study was limited to the year 2010 and it raises a question about the long-term evolution of anthropogenic related contamination, for example by $\mathrm{NO}_{3}^{-}$. The Bavarian Environmental Agency (Landesamt für Umwelt - LfU) operates a long-term monitoring station for basic river water chemistry near our lower-course sampling point Kirchehrenbach (8) (Figure 1). The mean annual average $\mathrm{NO}_{3}^{-}$concentrations for the period from 1985 to 2015 are shown in Table 1. The average values remained almost unchanged with an average value of $(19.5 \pm 1.0) \mathrm{mg} \mathrm{L}^{-1}$. A minor tendency to somewhat lower values can observed since 
485

$\sim 2008$, but overall the long-term data set indicates that our study is representative not only for 2010 , but also for any given period of time.

A valuable tool for future studies assessing the natural or anthropogenic origin of solute compounds, such as $\mathrm{NO}_{3}^{-}, \mathrm{SO}_{4}^{2-}$ or $\mathrm{Cl}^{-}$, are light stable isotope analyses of the elements C, H, O, N, S (e.g., Michalski et al., 2004; Bateman and Kelly, 2007; Liu et al., 2008; Widory et al., 2013; Amiri et al., 2015; Michalski et al., 2015). In addition, future studies should include ecological indicators that may be more sensitive to fertilizer input, such as counts of specific organisms and quantification of sediment loads.

Overall, our findings indicate that bedrock geology remains the dominant control on the major ion chemistry of the Wiesent River, and that agricultural influences are the strongest near the headwaters despite increased land-use further downstream, due to longterm storage and accumulation in karst aquifers. This feature may not be unique to the Wiesent River system, and subsequent work in other river systems could establish whether such patterns are ubiquitous worldwide.

Carbonate outcrops for Europe and the entire world are estimated with 22\% and 13\%, respectively (Williams and Ford, 2006; Hollingsworth, 2009; Williams and Fong, 2010), illustrating the global significance of karst. In karst regions, the source spring is the most important locale to obtain information about the functioning of the entire watershed system (Bakalowicz, 2005). Understanding the hydro-chemical pattern of rivers from their sources to lower reaches will facilitate freshwater security, ecosystem health, and the sustainability of drinking water resources. 
van Geldern et al. - Wiesent River major ions patterns

\section{ACKNOWLEDGMENTS}

507 We thank Irene Wein and Silke Meyer (FAU) for their help with laboratory work.

508 Additional chemical data and discharge values were kindly provided by Michael Lorenz

509 (Wasserwirtschaftsamt Kronach), Nadine Döhler and Joachim Stoermer (Landesamt für

510 Umwelt, LfU). Partial financial support was provided by the Deutsche

511 Forschungsgemeinschaft (DFG grants BA 2207/6-1 and INST 90/678-1 FUGG), the

512 European Commission H2020 Marie Skłodowska-Curie Action (grant 706088) and the

513 Universitätsbund of Friedrich-Alexander-Universität Erlangen-Nürnberg.

514

515 APPENDIX

516 Supplementary Material to this article is available at https://doi.org/10.1002/hyp.11461 and

517 from PANGAEA (www.pangaea.de) at https://doi.pangaea.de/10.1594/PANGAEA.885224. 518 


\section{References}

520 Allan JD, Castillo MM. 2007. Stream Ecology - Structure and function of running water. 2nd Edn., Springer; 445.

Amiri H, Zare M, Widory D. 2015. Assessing sources of nitrate contamination in the Shiraz urban aquifer (Iran) using the $\delta^{15} \mathrm{~N}$ and $\delta^{18} \mathrm{O}$ dual-isotope approach. Isotopes in Environmental and Health Studies 51: 392-410. DOI: 10.1080/10256016.2015.1032960.

Apel R, Büttner G. 1995. Nördliche Frankenalb - Hydrogeologie. Bayerisches Geologisches Landesamt (GLA); 119.

Atkinson TC. 1977. Diffuse flow and conduit flow in limestone terrain in the Mendip Hills, Somerset (Great Britain). Journal of Hydrology 35: 93-110. DOI: 10.1016/00221694(77)90079-8.

Aucour A-M, Sheppard SMF, Guyomar O, Wattelet J. 1999. Use of ${ }^{13} \mathrm{C}$ to trace origin and cycling of inorganic carbon in the Rhône river system. Chemical Geology 159: 87105. DOI: 10.1016/S0009-2541(99)00035-2.

Aufdenkampe AK, Mayorga E, Raymond PA, Melack JM, Doney SC, Alin SR, Aalto RE, Yoo K. 2011. Riverine coupling of biogeochemical cycles between land, oceans, and atmosphere. Frontiers in Ecology and the Environment 9: 53-60. DOI: $10.1890 / 100014$.

Bakalowicz M. 2005. Karst groundwater: a challenge for new resources. Hydrogeology Journal 13: 148-160. DOI: 10.1007/s10040-004-0402-9.

540 Barth JAC, Cronin AA, Dunlop J, Kalin RM. 2003. Influence of carbonates on the riverine carbon cycle in an anthropogenically dominated catchment basin: Evidence from 
van Geldern et al. - Wiesent River major ions patterns

major elements and stable carbon isotopes in the Lagan River (N. Ireland). Chemical Geology 200: 203-216.

Bateman AS, Kelly SD. 2007. Fertilizer nitrogen isotope signatures. Isotopes in Environmental and Health Studies 43: 237-247. DOI: 10.1080/10256010701550732.

Berner RA, Lasaga AC, Garrels RM. 1983. The carbonate-silicate geochemical cycle and its effect on atmospheric carbon dioxide over the past 100 million years. American Journal of Science 283: 641-683.

Biggs TW, Dunne T, Domingues TF, Martinelli LA. 2002. Relative influence of natural watershed properties and human disturbance on stream solute concentrations in the southwestern Brazilian Amazon basin. Water Resources Research 38: 25-21-25-16. DOI: $10.1029 / 2001$ WR000271.

Brunet F, Potot C, Probst A, Probst JL. 2011. Stable carbon isotope evidence for nitrogenous fertilizer impact on carbonate weathering in a small agricultural watershed. Rapid Communications in Mass Spectrometry 25: 2682-2690. DOI: 10.1002/rcm.5050.

Bukaveckas PA. 2010. Hydrology: Rivers. In: River Ecosystem Ecology: A Global Perspective, Likens GE (ed.) Academic Press, pp: 32-44.

Cartwright I. 2010. The origins and behaviour of carbon in a major semi-arid river, the Murray River, Australia, as constrained by carbon isotopes and hydrochemistry. Applied Geochemistry 25: 1734-1745. DOI: 10.1016/j.apgeochem.2010.08.020.

Chetelat B, Liu CQ, Zhao ZQ, Wang QL, Li SL, Li J, Wang BL. 2008. Geochemistry of the dissolved load of the Changjiang Basin rivers: Anthropogenic impacts and chemical weathering. Geochimica et Cosmochimica Acta 72: 4254-4277. DOI: 10.1016/j.gca.2008.06.013. 
van Geldern et al. - Wiesent River major ions patterns

565 Clark I, Fritz P. 1997. Environmental Isotopes in Hydrology. CRC Press, Boca Raton, FL; $566 \quad 328$.

567 Cook PG, Herczeg AL. 2000. Environmental Tracers in Subsurface Hydrology. Springer, $568 \quad$ New York; 529.

569 Daesslé LW, van Geldern R, Orozco-Durán A, Barth JAC. 2016. The 2014 water release into the arid Colorado River delta and associated water losses by evaporation. Science of the Total Environment 542: 586-590. DOI: 10.1016/j.scitotenv.2015.09.157.

Daesslé LW, Orozco A, Struck U, Camacho-Ibar VF, van Geldern R, Santamaría-del-Angel E, Barth JAC. 2017. Sources and sinks of nutrients and organic carbon during the 2014 pulse flow of the Colorado River into Mexico. Ecological Engineering 106: 799-808. DOI: 10.1016/j.ecoleng.2016.02.018.

Doctor DH, Kendall C, Sebestyen SD, Shanley JB, Ote N, Boyer EW. 2008. Carbon isotope fractionation of dissolved inorganic carbon (DIC) due to outgassing of carbon dioxide from a headwater stream. Hydrological Processes 22: 2410-2423. DOI: 10.1002/hyp.6833.

580 Engelhardt I, Barth JAC, Bol R, Schulz M, Ternes TA, Schüth C, van Geldern R. 2014. Quantification of long-term wastewater fluxes at the surface water/groundwaterinterface: An integrative model perspective using stable isotopes and acesulfame. Science of the Total Environment 466-467: 16-25. DOI: 10.1016/j.scitotenv.2013.06.092.

EPA. 1999. Background report on fertilzer use, contaminants and regulations. Office of Pollution Prevention and Toxics, Unites States Environmental Protection Agency (EPA), EPA 747-R-98-003; 121. 
589 Flintrop C, Hohlmann B, Jasper T, Korte C, Podlaha OG, Scheele S, Veizer J. 1996. Anatomy of pollution; rivers of North Rhine-Westphalia, Germany. American Journal of Science 296: 58-98. DOI: 10.2475/ajs.296.1.58.

592 Ford DC, Williams PW. 1989. Karst Geomorphology and Hydrogeology. Chapman and Hall, London; 601.

594 Ford DC, Williams PW. 2007. Karst Hydrogeology and Geomorphology. John Wiley \& Sons, 595 Chichester; 576.

596

Fox A, Laube G, Schmidt C, Fleckenstein JH, Arnon S. 2016. The effect of losing and gaining flow conditions on hyporheic exchange in heterogeneous streambeds. Water Resources Research 52: 7460-7477. DOI: 10.1002/2016WR018677.

Gaillardet J, Dupre B, Allegre CJ, Negrel P. 1997. Chemical and physical denudation in the Amazon River basin. Chemical Geology 142: 141-173. DOI: 10.1016/S00092541(97)00074-0.

Gaillardet J, Dupre B, Louvat P, Allegre CJ. 1999. Global silicate weathering and $\mathrm{CO}_{2}$ consumption rates deduced from the chemistry of large rivers. Chemical Geology 159: 3-30. DOI: 10.1016/S0009-2541(99)00031-5.

Galy A, France-Lanord C. 1999. Weathering processes in the Ganges-Brahmaputra basin and the riverine alkalinity budget. Chemical Geology 159: 31-60. DOI: 10.1016/S00092541(99)00033-9.

Gandois L, Perrin A-S, Probst A. 2011. Impact of nitrogenous fertiliser-induced proton release on cultivated soils with contrasting carbonate contents: A column experiment. Geochimica et Cosmochimica Acta 75: 1185-1198. DOI: 10.1016/j.gca.2010.11.025.

Gibbs RJ. 1970. Mechanisms Controlling World Water Chemistry. Science 170: 1088. 
van Geldern et al. - Wiesent River major ions patterns

612 Gleick PH. 1996. Water resources. In: Encyclopedia of Climate and Weather, Schneider SH (ed.) Oxford University Press, New York, pp: 817-823.

614 Goldscheider N, Drew D. 2007. Methods in Karst Hydrogeology. Taylor \& Francis, London, $615 \quad$ pp: 264.

616 Grosbois C, Négrel P, Fouillac C, Grimaud D. 2000. Dissolved load of the Loire River:

617 Chemical and isotopic characterization. Chemical Geology 170: 179-201. DOI:

$618 \quad 10.1016 / \mathrm{S} 0009-2541(99) 00247-8$.

619 Hélie J-F, Hillaire-Marcel C, Rondeau B. 2002. Seasonal changes in the sources and fluxes of 620 dissolved inorganic carbon through the St. Lawrence River-isotopic and chemical constraint. Chemical Geology 186: 117-138. DOI: 10.1016/S0009-2541(01)00417-X.

622

624

625

626

627

628

629

630

631

632

633

634
Hollingsworth E. 2009. Karst Regions of the World (KROW)---Populating global karst datasets and generating maps to advance the understanding of karst occurrence and protection of karst species and habitats worldwide. University of Arkansas, MSc Science thesis; available online: www.karstportal.org/download/file/fid/244 (accessed 31 March 2014); 129.

Huebsch M, Fenton O, Horan B, Hennessy D, Richards KG, Jordan P, Goldscheider N, Butscher C, Blum P. 2014. Mobilisation or dilution? Nitrate response of karst springs to high rainfall events. Hydrology and Earth System Sciences 18: 4423-4435. DOI: 10.5194/hess-18-4423-2014.

Jiang Y, Wu Y, Groves C, Yuan D, Kambesis P. 2009. Natural and anthropogenic factors affecting the groundwater quality in the Nandong karst underground river system in Yunan, China. Journal of Contaminant Hydrology 109: 49-61. DOI: 10.1016/j.jconhyd.2009.08.001. 
635 Kanduč T, Mori N, Kocman D, Stibilj V, Grassa F. 2012. Hydrogeochemistry of Alpine springs from North Slovenia: Insights from stable isotopes. Chemical Geology 300301: 40-54. DOI: 10.1016/j.chemgeo.2012.01.012.

Kanduč T, Šturm MB, McIntosh J. 2013. Chemical Dynamics and Evaluation of Biogeochemical Processes in Alpine River Kamniška Bistrica, North Slovenia. Aquatic Geochemistry 19: 323-346. DOI: 10.1007/s10498-013-9197-4.

Kanduč T, Szramek K, Ogrinc N, Walter L. 2007. Origin and cycling of riverine inorganic carbon in the Sava River watershed (Slovenia) inferred from major solutes and stable carbon isotopes. Biogeochemistry 86: 137-154. DOI: 10.1007/s10533-007-9149-4.

Kelly WR, Panno SV, Hackley K. 2012. The Sources, Distribution, and Trends of Chloride in the Waters of Illinois. Illinois State Water Survey, Champaign, IL; 67.

646 Kendall C, Silva SR, Kelly VJ. 2001. Carbon and nitrogen isotopic compositions of particulate organic matter in four large river systems across the United States. Hydrological Processes 15: 1301-1346. DOI: 10.1002/hyp.216.

Kiraly L. 1998. Modelling karst aquifers by the combined discrete chan- nel and continuum approach. Bulletin d'Hydrogéologie 16: 77-98. http://doc.rero.ch/record/260628

651 Krause S, Boano F, Cuthbert MO, Fleckenstein JH, Lewandowski J. 2014. Understanding process dynamics at aquifer-surface water interfaces: An introduction to the special section on new modeling approaches and novel experimental technologies. Water Resources Research 50: 1847-1855. DOI: 10.1002/2013WR014755. groundwater-surface water interface. Hydrological Processes 23: 2103-2107. DOI: 10.1002/hyp.7366. 
658 Krumbeck L. 1956. Erläuterungen zur Geologischen Karte von Bayern 1: 25000 - Blatt Nr. 6232 Forchheim. Bayerisches Geologisches Landesamt; 80.

660 Lee K, van Geldern R, Barth JAC. 2017. A high-resolution carbon balance in a temperate catchment: insights from the Schwabach River, Germany. Applied Geochemistry $\mathbf{8 5}$ : 86-96. DOI: 10.1016/j.apgeochem.2017.08.007.

LfU. 2014. Hochwassernachrichtendienst. Bayerisches Landesamt für Umwelt (LfU). Accessible at http://www.hnd.bayern.de, (last accessed 28 Feb 2014). Diego, pp: 424. Natural Inputs of Sulfate and Chloride into the Karstic Ground Water of Guiyang,

Lowson RT. 1982. Aqueous oxidation of pyrite by molecular oxygen. Chemical Reviews 82: 461-497. DOI: 10.1021/cr00051a001.

Marx A, Dusek J, Jankovec J, Sanda M, Vogel T, van Geldern R, Hartmann J, Barth JAC. 2017a. A review of $\mathrm{CO}_{2}$ and associated carbon dynamics in headwater streams: a global perspective. Reviews of Geophysics 55: 560-585. DOI: 10.1002/2016RG000547. R, Barth JAC. 2017b. Acid rain footprint three decades after peak deposition: Longterm recovery from pollutant sulphate in the Uhlirska catchment (Czech Republic). Science of the Total Environment 598: 1037-1049. DOI: 10.1016/j.scitotenv.2017.04.109. 
van Geldern et al. - Wiesent River major ions patterns

682 Meybeck M. 1982. Carbon, nitrogen, and phosphorus transport by world rivers. American Journal of Science 282: 401-450. DOI: 10.2475/ajs.282.4.401.

684

685

686

687

688

689

690

691

692

693

694

695

696

697

698

699

700

701

702

703

704

705

Meybeck M. 1987. Global chemical weathering of surficial rocks estimated from river dissolved loads. American Journal of Science 287: 401-428. DOI: 10.2475/ajs.287.5.401.

Michalski G, Böhlke JK, Thiemens M. 2004. Long term atmospheric deposition as the source of nitrate and other salts in the Atacama Desert, Chile: New evidence from massindependent oxygen isotopic compositions. Geochimica et Cosmochimica Acta $\mathbf{6 8}$ : 4023-4038. DOI: 10.1016/j.gca.2004.04.009.

Michalski G, Kolanowski M, Riha KM. 2015. Oxygen and nitrogen isotopic composition of nitrate in commercial fertilizers, nitric acid, and reagent salts. Isotopes in Environmental and Health Studies 51: 382-391. DOI:

$10.1080 / 10256016.2015 .1054821$

Milliman JD, Farnsworth KL. 2011. River Discharge to the Coastal Ocean: A Global Synthesis. Cambridge University Press, Cambridge; 392.

Mullaney JR, Lorenz DL, Arntson AD. 2009. Chloride in Groundwater and Surface Water in Areas Underlain by the Glacial Aquifer System, Northern United States. U.S. Geological Survey Scientic Investigations Report 2009-5086; 41.

Négrel P, Allègre CJ, Dupré B, Lewin E. 1993. Erosion sources determined by inversion of major and trace element ratios and strontium isotopic ratios in river: The Congo Basin case. Earth and Planetary Science Letters 120: 59-76. DOI: 10.1016/0012821X(93)90023-3.

Perrin A-S, Probst A, Probst J-L. 2008. Impact of nitrogenous fertilizers on carbonate dissolution in small agricultural catchments: Implications for weathering CO2 uptake 
van Geldern et al. - Wiesent River major ions patterns

706

707

708

709

710

711

712

713

714

715

716

717

718

719

720

721

722

723

724

725

726

727

728

729

at regional and global scales. Geochimica et Cosmochimica Acta 72: 3105-3123.

DOI: 10.1016/j.gca.2008.04.011.

Perrin J, Jeannin PY, Cornaton F. 2007. The role of tributary mixing in chemical variations at a karst spring, Milandre, Switzerland. Journal of Hydrology 332: 158-173. DOI: 10.1016/j.jhydrol.2006.06.027.

Piper AM. 1944. A graphic procedure in the geochemical interpretation of water analysis. Transactions American Geophysical Union 25: 914-923. DOI: 10.1029/TR025i006p00914.

Probst A, Viville D, Fritz B, Ambroise B, Dambrine E. 1992. Hydrochemical budgets of a small forested granitic catchment exposed to acid deposition: The strengbach catchment case study (Vosges massif, France). Water, Air, \& Soil Pollution 62: 337347. DOI: 10.1007/BF00480265.

Raymond PA, Hartmann J, Lauerwald R, Sobek S, McDonald C, Hoover M, Butman D, Striegl R, Mayorga E, Humborg C, Kortelainen P, Durr H, Meybeck M, Ciais P, Guth P. 2013. Global carbon dioxide emissions from inland waters. Nature 503: 355 359. DOI: $10.1038 /$ nature 12760.

Raymond PA, Oh N-H, Turner RE, Broussard W. 2008. Anthropogenically enhanced fluxes of water and carbon from the Mississippi River. Nature 451: 449-452. DOI: 10.1038/nature06505.

Richey JE, Melack JM, Aufdenkampe AK, Ballester VM, Hess LL. 2002. Outgassing from Amazonian rivers and wetlands as a large tropical source of atmospheric $\mathrm{CO} 2$. Nature 416: 617-620. DOI: 10.1038/416617a.

Rosa E, Gaillardet J, Hillaire-Marcel C, Hélie J-F, Richard L-F. 2012. Rock denudation rates and organic carbon exports along a latitudinal gradient in the Hudson, James, and 
van Geldern et al. - Wiesent River major ions patterns

Ungava bays watershed. Canadian Journal of Earth Sciences 49: 742-757. DOI: 10.1139/e2012-021.

Schröder B. 1968. Erläuterungen zur Geologischen Karte von Bayern 1:25000 - Blatt Nr. 6332 Erlangen Nord. Bayerisches Geologisches Landesamt; 159.

Seitzinger SP, Mayorga E, Bouwman AF, Kroeze C, Beusen AHW, Billen G, Van Drecht G, Dumont E, Fekete BM, Garnier J, Harrison JA. 2010. Global river nutrient export: A scenario analysis of past and future trends. Global Biogeochemical Cycles 24: GB0A08. DOI: 10.1029/2009GB003587.

Semhi K, Amiotte Suchet P, Clauer N, Probst JL 2000. Impact of nitrogen fertilizers on the natural weathering- erosion processes and fuvial transport in the Garonne basin. Applied Geochemistry 15: 865-878. DOI: 10.1016/S0883-2927(99)00076-1.

Soulsby C, Tetzlaff D, van den Bedem N, Malcolm IA, Bacon PJ, Youngson AF. 2007. Inferring groundwater influences on surface water in montane catchments from hydrochemical surveys of springs and streamwaters. Journal of Hydrology 333: 199213. DOI: $10.1016 /$ j.jhydrol.2006.08.016.

Stögbauer A, Strauss H, Arndt J, Marek V, Einsiedl F, van Geldern R. 2008. Rivers of NorthRhine Westphalia revisited: Tracing changes in river chemistry. Applied Geochemistry 23: 3290-3304. DOI: 10.1016/j.apgeochem.2008.06.030.

Struyf E, Smis A, Van Damme S, Meire P, Conley DJ. 2009. The Global Biogeochemical Silicon Cycle. Silicon 1: 207-213. DOI: 10.1007/s12633-010-9035-x.

Sun H, Alexander J, Gove B, Pezzi E, Chakowski N, Husch J. 2014. Mineralogical and anthropogenic controls of stream water chemistry in salted watersheds. Applied Geochemistry 48: 141-154. DOI: 10.1016/j.apgeochem.2014.06.028. 
van Geldern et al. - Wiesent River major ions patterns

753

754

755

756

757

758

759

760

761

762

763

764

765

766

767

768

769

770

771

772

773

774

775

776

Szramek K, McIntosh JC, Williams EL, Kanduc T, Ogrinc N, Walter LM. 2007. Relative weathering intensity of calcite versus dolomite in carbonate-bearing temperate zone watersheds: Carbonate geochemistry and fluxes from catchments within the St. Lawrence and Danube river basins. Geochemistry, Geophysics, Geosystems 8. DOI: 10.1029/2006GC001337.

Torres MA, Baronas JJ, Clark KE, Feakins SJ, West AJ. 2017. Mixing as a driver of temporal variations in river hydrochemistry: 1 . Insights from conservative tracers in the Andes-Amazon transition. Water Resources Research 53: 3102-3119. DOI: 10.1002/2016WR019733.

van Geldern R, Schulte P, Mader M, Baier A, Barth JAC. 2015. Spatial and temporal variations of $p \mathrm{CO}_{2}$, dissolved inorganic carbon and stable isotopes along a temperate karstic watercourse. Hydrological Processes 29: 3423-3440. DOI: 10.1002/hyp.10457.

Verma MP, Portugal E, Gangloff S, Armienta MA, Chandrasekharam D, Sanchez M, Renderos RE, Juanco M, van Geldern R. 2015. Determination of carbonic species concentration in natural waters - Results from a worldwide proficiency test. Geostandards and Geoanalytical Research 39: 233-255. DOI: 10.1111/j.1751908X.2014.00306.x.

Viers J, Dupré B, Gaillardet J. 2009. Chemical composition of suspended sediments in World Rivers: New insights from a new database. Science of the Total Environment 407: 853-868. DOI: 10.1016/j.scitotenv.2008.09.053.

Voss BM, Peucker-Ehrenbrink B, Eglinton TI, Fiske G, Wang ZA, Hoering KA, Montluçon DB, LeCroy C, Pal S, Marsh S, Gillies SL, Janmaat A, Bennett M, Downey B, Fanslau J, Fraser H, Macklam-Harron G, Martinec M, Wiebe B. 2014. Tracing river 
van Geldern et al. - Wiesent River major ions patterns

chemistry in space and time: Dissolved inorganic constituents of the Fraser River, Canada. Geochimica et Cosmochimica Acta 124: 283-308. DOI: 10.1016/j.gca.2013.09.006.

White WB. 1988. Geomorphology and hydrology of karst terrains. Oxford University Press, New York; 464.

Widory D, Petelet-Giraud E, Brenot A, Bronders J, Tirez K, Boeckx P. 2013. Improving the management of nitrate pollution in water by the use of isotope monitoring: the $\delta^{15} \mathrm{~N}$, $\delta^{18} \mathrm{O}$ and $\delta^{11} \mathrm{~B}$ triptych. Isotopes in Environmental and Health Studies 49: 29-47. DOI: $10.1080 / 10256016.2012 .666540$.

Williams P, Fong YT. 2010. World Map of Carbonate Rock Outcrops v3.0. Accessible at http://web.env.auckland.ac.nz/our_research/karst/.

Williams PW, Ford DC. 2006. Global distribution of carbonate rocks. Zeitschrift für Geomorphologie Supplement 147: 1-2.

Winter T, Harvey J, Franke O, Alley W. 1998. Groundwater and surface water - A single resource. US Geological Survey Circular 1139; 79.

Wippern J. 1955. Erläuterungen zur Geologischen Karte von Bayern 1: 25000 - Blatt Nr. 6134 Waischenfeld. Bayerisches Geologisches Landesamt; 47.

Wollast R, Mackenzie FT. 1983. The global cycle of silica. In: Silicon geochemistry and biochemistry, Aston SR (ed.) Academic Press, San Diengo; pp: 39-76.

Yang C, Telmer K, Veizer J. 1996. Chemical dynamics of the "St. Lawrence” riverine system: $\delta \mathrm{D}_{\mathrm{H} 2 \mathrm{O}}, \delta^{18} \mathrm{O}_{\mathrm{H} 2 \mathrm{O}}, \delta^{13} \mathrm{C}_{\mathrm{DIC}}, \delta^{34} \mathrm{~S}_{\text {sulfate, }}$ and dissolved ${ }^{87} \mathrm{Sr} /{ }^{86} \mathrm{Sr}$. Geochimica et Cosmochimica Acta 60: 851-866. DOI: 10.1016/0016-7037(95)00445-9.

Zavadlav S, Kanduč T, McIntosh J, Lojen S. 2013. Isotopic and Chemical Constraints on the Biogeochemistry of Dissolved Inorganic Carbon and Chemical Weathering in the 
van Geldern et al. - Wiesent River major ions patterns

801

802

803 Zhang J, Zhang ZF, Liu SM, Wu Y, Xiong H, Chen HT. 1999. Human impacts on the large

804

805

806

807

Karst Watershed of Krka River (Slovenia). Aquatic Geochemistry 19: 209-230. DOI: 10.1007/s10498-013-9188-5.

world rivers: Would the Changjiang (Yangtze River) be an illustration? Global Biogeochemical Cycles 13: 1099-1105. DOI: 10.1029/1999GB900044. 


\section{FIGURE CAPTIONS}

809 Figure 1. Location of the study area in Southern Germany, sampling points and lithology of the Wiesent catchment. Sampling points are indicated for the Wiesent main river (numbers in

811 circles) and tributaries (numbers in square boxes). The total area of the Wiesent Catchment is $8121,040 \mathrm{~km}^{2}$.

814 Figure 2. Schematic hydrogeologic cross section of the northern Franconian Alb (modified 815 after (modifed after Apel and Büttner, 1995). Lias, Dogger, and Malm are German regional 816 names of Jurassic series.

818 Figure 3. Land cover along the Wiesent River and tributaries. Data is based on the CORINE 819 Land Cover 2006 (CLC 2006) and the hydrographic reference set EU-Hydro of the European Union Copernicus Land Monitoring Service (https://land.copernicus.eu).

Figure 4. Major ion chemistry, electric conductivity (EC), and temperature (T) along the Wiesent River. Additional data ( $\mathrm{pH}, \mathrm{O}_{2}$, environmental isotopes, discharge, precipitation) is available from the Supplementary Material to this article and from van Geldern et al. (2015).

Figure 5. Piper diagram for the Wiesent River and sampled tributaries. Numbers in parentheses refer to sampling locations. The tributaries Truppach (10) and Puettlach (12) mainly drain claystone and sandstone dominated lithology.

830 Figure 6. (A) $\mathrm{Ca}^{2+}$ plus $\mathrm{Mg}^{2+}$ plotted against $\mathrm{HCO}_{3}^{-}$concentrations (expressed in meq $\mathrm{L}^{-1}$ ) of 831 the Wiesent River. The dashed line indicates the stoichiometric relation of carbonate 
van Geldern et al. - Wiesent River major ions patterns

832 weathering. (B) $\mathrm{Na}^{+}$plus $\mathrm{K}^{+}$plotted against $\mathrm{Cl}^{-}$concentrations (expressed in meq $\mathrm{L}^{-1}$ ). The 833 dashed line indicates the stoichiometric relationship for salt dissolution. 


\section{TABLES}

Table 1. Long-term nitrate concentrations (1985 - 2015, arithmetic annual means) measured at the water quality monitoring station located at the lower Wiesent river course ("Reuth, KW Oberwasser", station ID 18423). Data available from the Bavarian Environmental Agency (LfU) at http://www.gkd.bayern.de (last accessed 20 January 2018).

\begin{tabular}{|c|c|c|}
\hline $\begin{array}{c}\text { calendar } \\
\text { year }\end{array}$ & $\begin{array}{c}\mathrm{NO}_{3}^{-} \\
/ \mathrm{mg} \mathrm{L}^{-1}\end{array}$ & $\begin{array}{c}\text { number of } \\
\text { value per year }\end{array}$ \\
\hline 1985 & 18.2 & 24 \\
\hline 1986 & 20.3 & 27 \\
\hline 1987 & 19.0 & 27 \\
\hline 1988 & 18.2 & 26 \\
\hline 1989 & 18.9 & 27 \\
\hline 1990 & 18.8 & 26 \\
\hline 1991 & 19.3 & 26 \\
\hline 1992 & 18.5 & 26 \\
\hline 1993 & 20.2 & 26 \\
\hline 1994 & 19.4 & 26 \\
\hline 1995 & 20.6 & 26 \\
\hline 1996 & 19.1 & 26 \\
\hline 1997 & 19.9 & 27 \\
\hline 1998 & 19.9 & 26 \\
\hline 1999 & 20.4 & 26 \\
\hline 2000 & 21.3 & 26 \\
\hline 2001 & 19.8 & 26 \\
\hline 2002 & 20.1 & 25 \\
\hline 2003 & 19.5 & 26 \\
\hline 2004 & 20.6 & 26 \\
\hline 2005 & 20.9 & 26 \\
\hline 2006 & 20.3 & 25 \\
\hline 2007 & 20.7 & 26 \\
\hline 2008 & 20.3 & 24 \\
\hline 2009 & 19.6 & 26 \\
\hline 2010 & 19.0 & 25 \\
\hline 2011 & 19.9 & 25 \\
\hline 2012 & 18.6 & 26 \\
\hline 2013 & 17.7 & 26 \\
\hline 2014 & 17.6 & 13 \\
\hline 2015 & 18.2 & 13 \\
\hline average & $(19.5 \pm 1.0)$ & \\
\hline
\end{tabular}




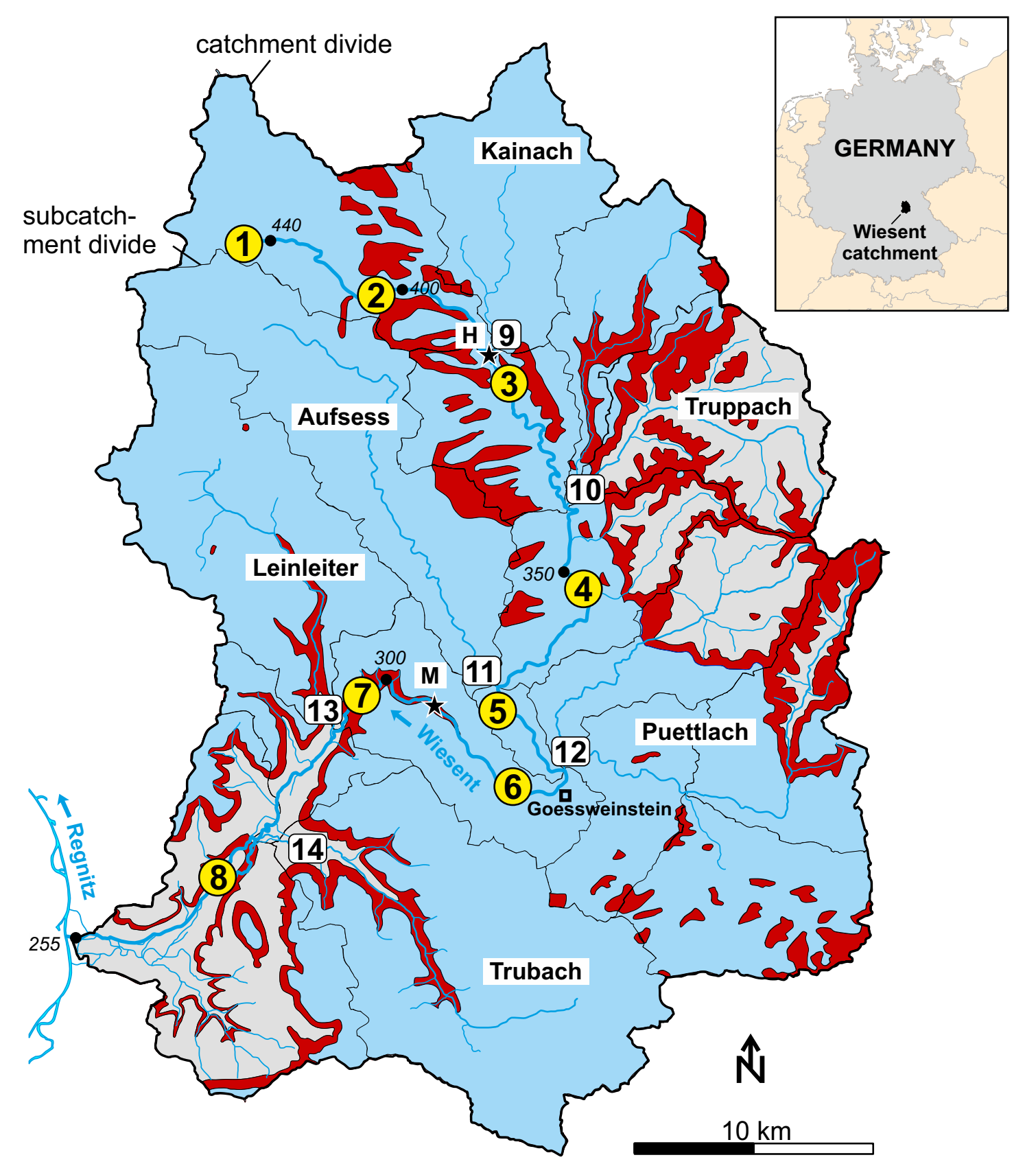

\section{Locations}

limestone

sandstone (with clay layers) claystone

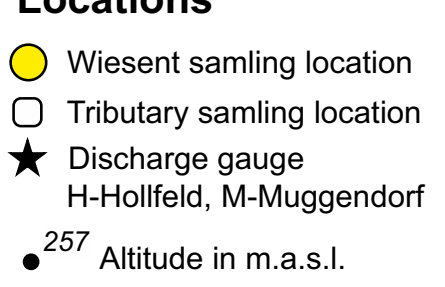

\section{Wiesent River}

1 - Steinfeld (source)

2 - Wiesentfels

3 - Hollfeld

4 - Waischenfeld

5 - Doos

6 - Goessweinstein

7 - Streitberg

8 - Kirchehrenbach and LfU water quality monitoring station
Tributaries

9 - Kainach

10 - Truppach

11 - Aufsess

12 - Puettlach

13 - Leinleiter

14 - Trubach

Figure 1. Location of the study area in Southern Germany, sampling points and lithology of the Wiesent catchment. Sampling points are indicated for the Wiesent main river (numbers in circles) and tributaries (numbers in square boxes). The total area of the Wiesent Catchment is $1,040 \mathrm{~km} 2$. 


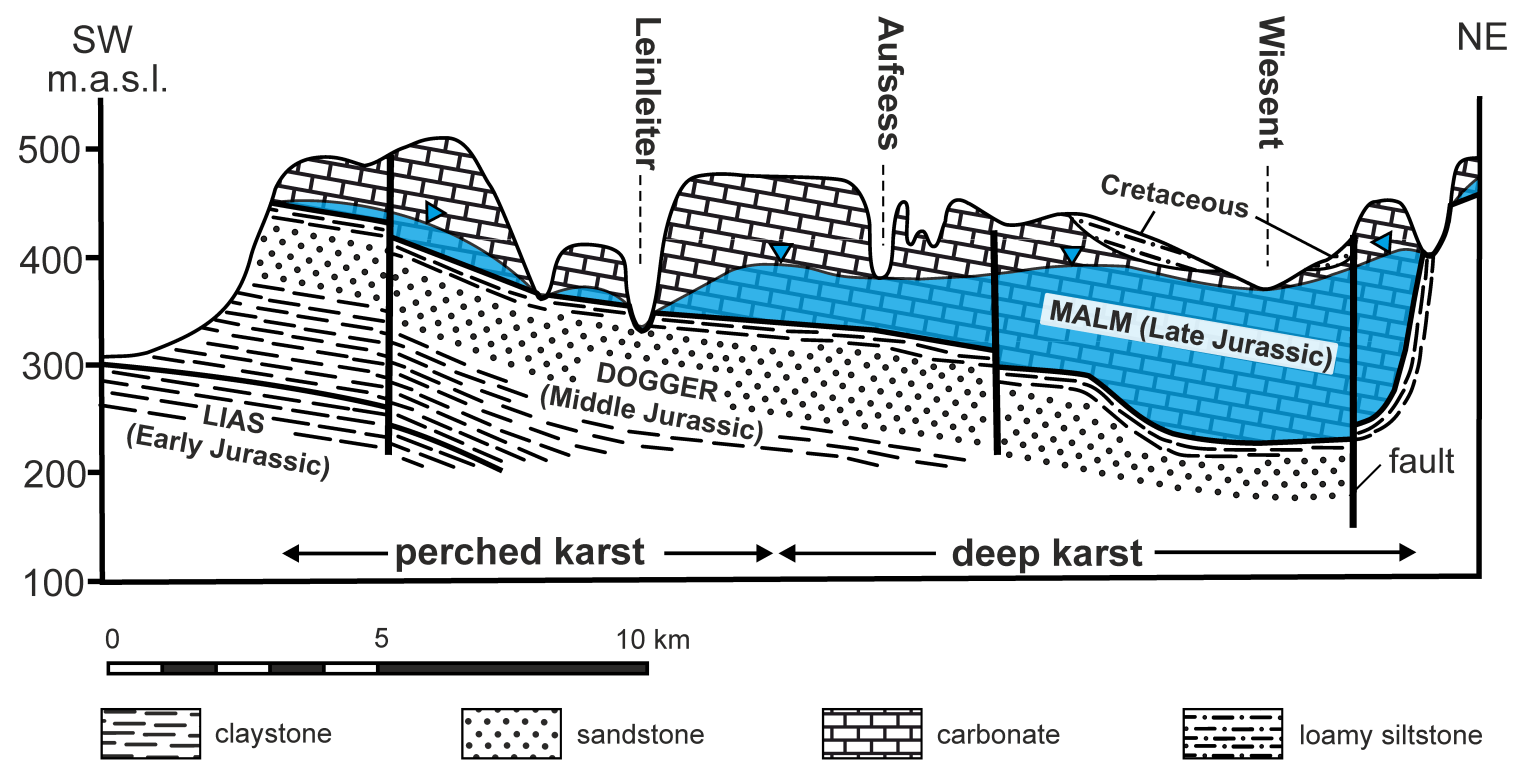

Figure 2. Schematic hydrogeologic cross section of the northern Franconian Alb (modified after (modifed after Apel and Büttner, 1995). Lias, Dogger, and Malm are German regional names of Jurassic series. 


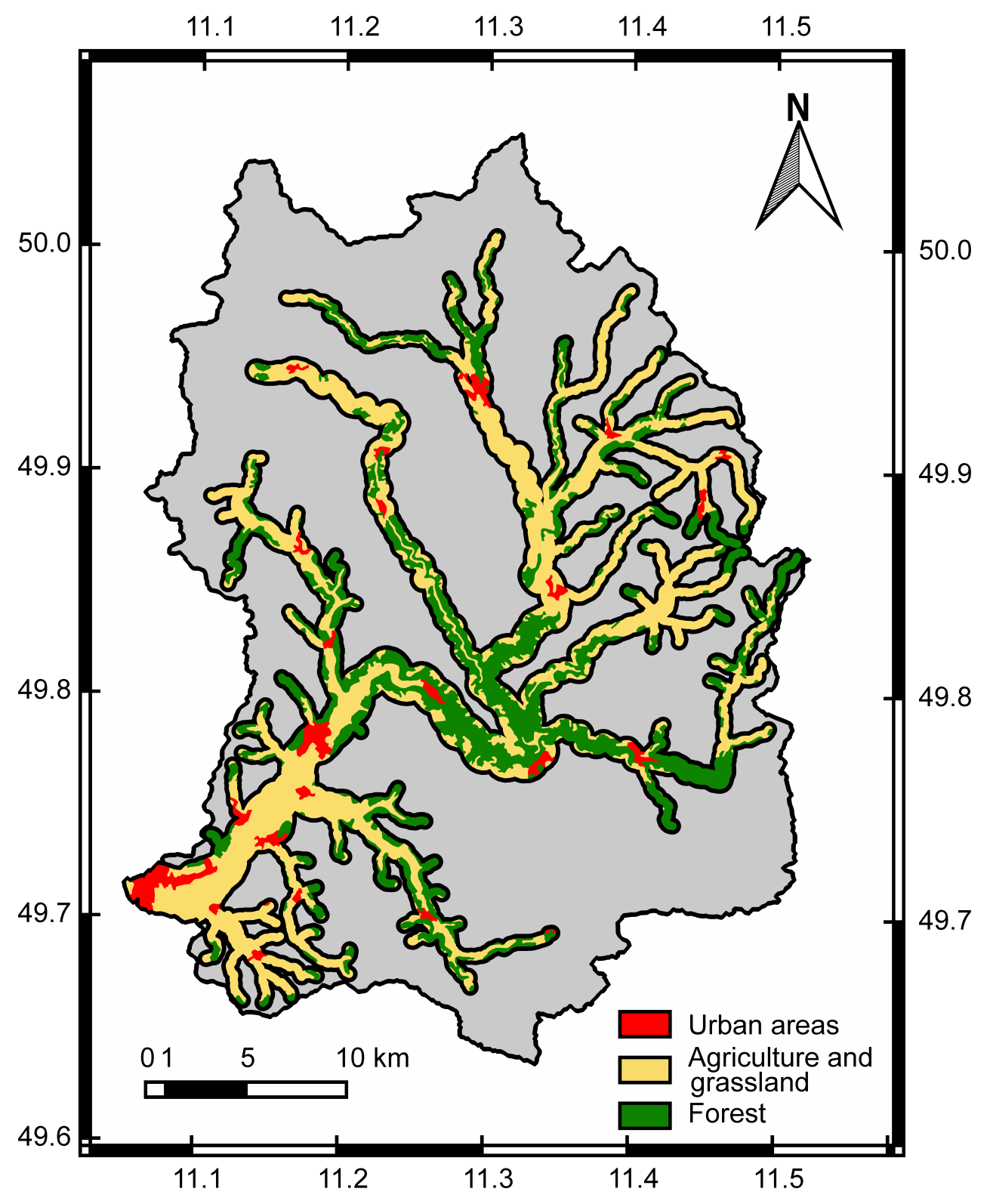

Figure 3. Land cover along the Wiesent River and tributaries. Data is based on the CORINE Land Cover 2006 (CLC 2006) and the hydrographic reference set EU-Hydro of the European Union Copernicus Land Monitoring Service (https://land.copernicus.eu). 

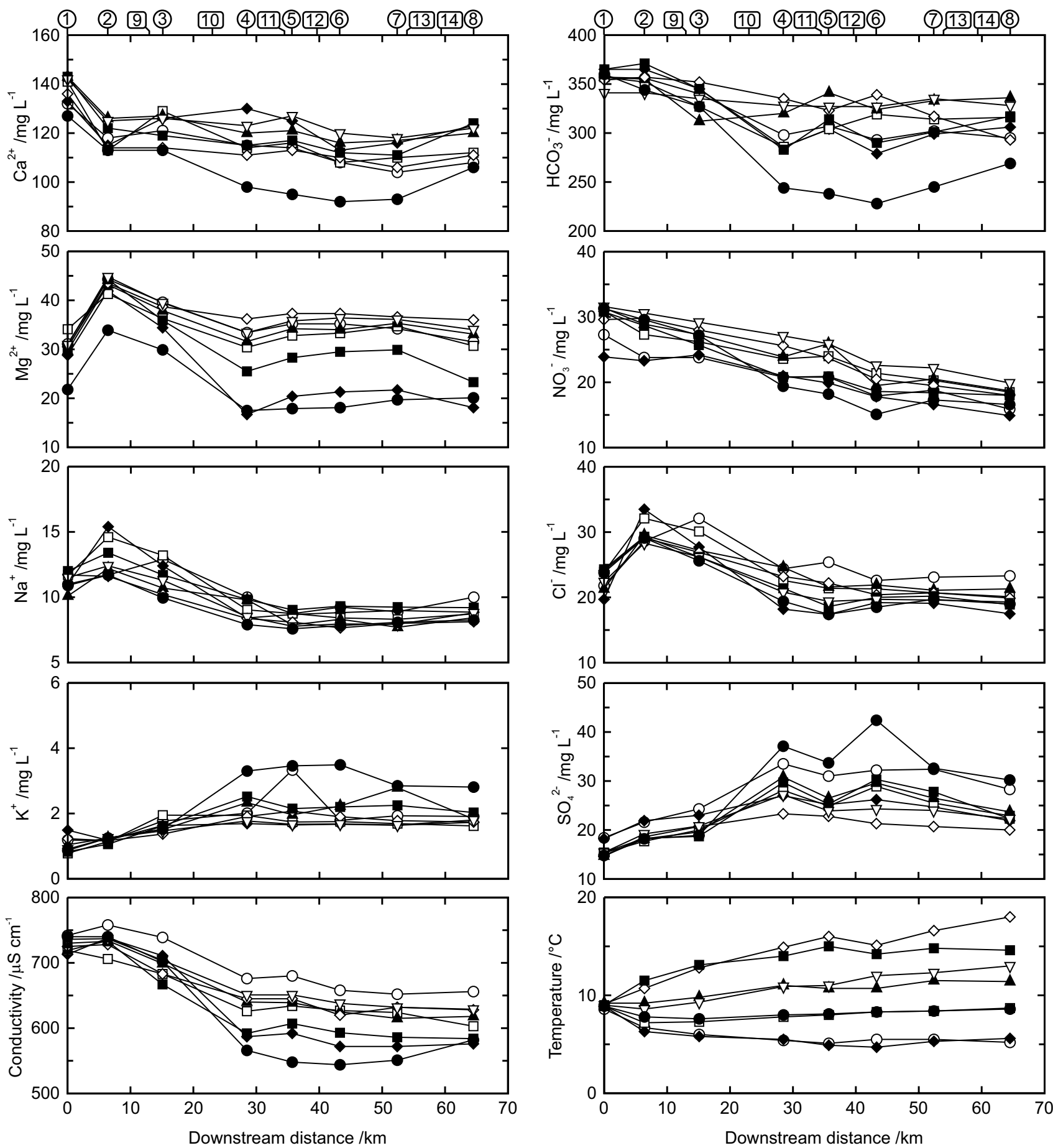

Date 2010

$\multimap 19 \mathrm{Feb} \neg \square-12 \mathrm{Apr} \smile 19 \mathrm{Jul} \rightarrow-23 \mathrm{Sep}$

Figure 4. Major ion chemistry, electric conductivity (EC), and temperature ( $\mathrm{T}$ ) along the Wiesent River. Additional data (pH, O2, environmental isotopes, discharge, precipitation) is available from the Supplementary Material to this article and from van

Geldern et al. (2015). 
O Wiesent (1-8)

Tributaries:

- Kainach (9)

- Truppbach (10)

- Aufsess (11)

$\nabla \quad$ Puettlach (12)

* Leinleiter (13)

$\square \quad$ Trubach (14)
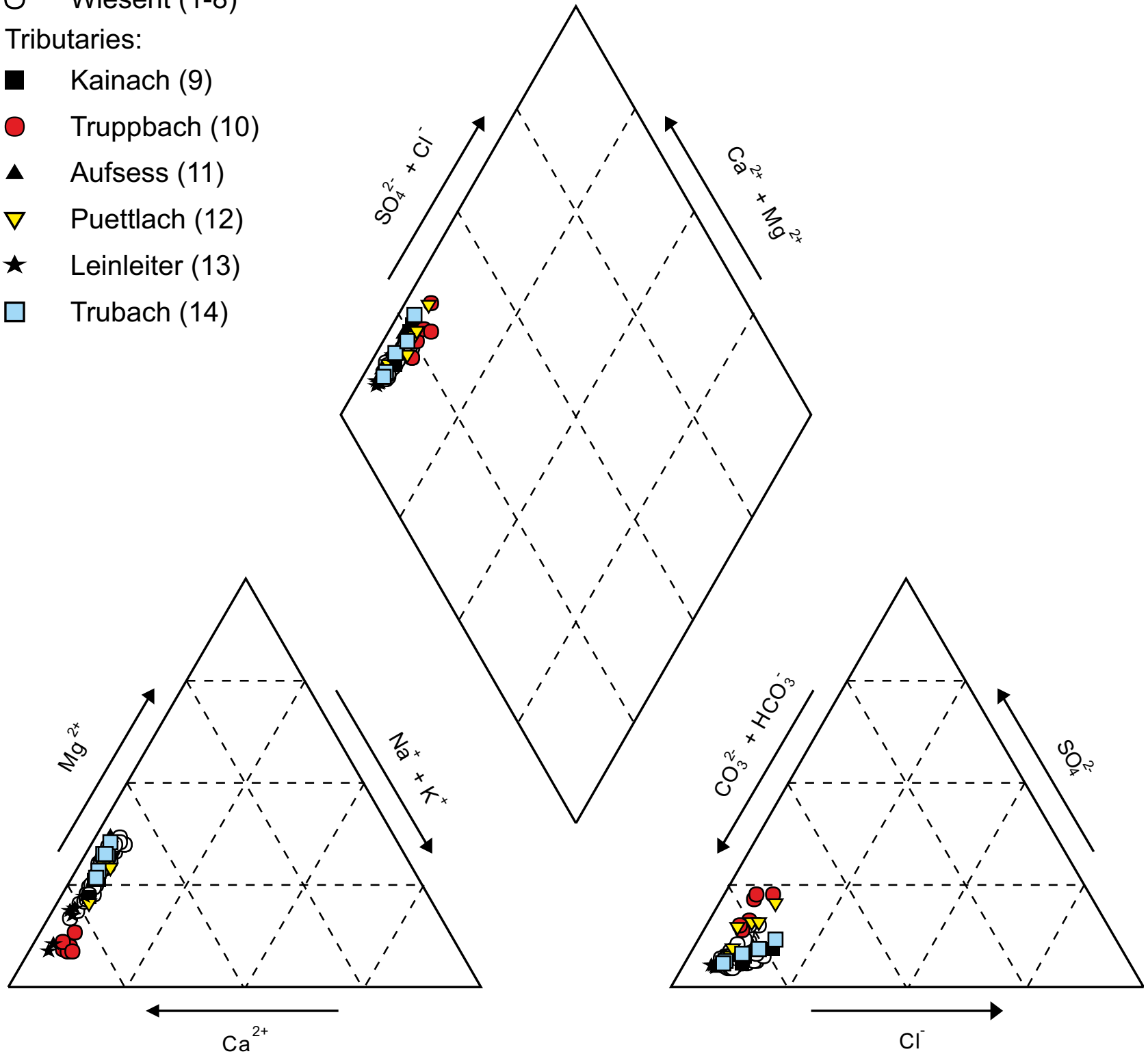

Figure 5. Piper diagram for the Wiesent River and sampled tributaries. Numbers in parentheses refer to sampling locations. The tributaries Truppach (10) and Puettlach (12) mainly drain claystone and sandstone dominated lithology. 

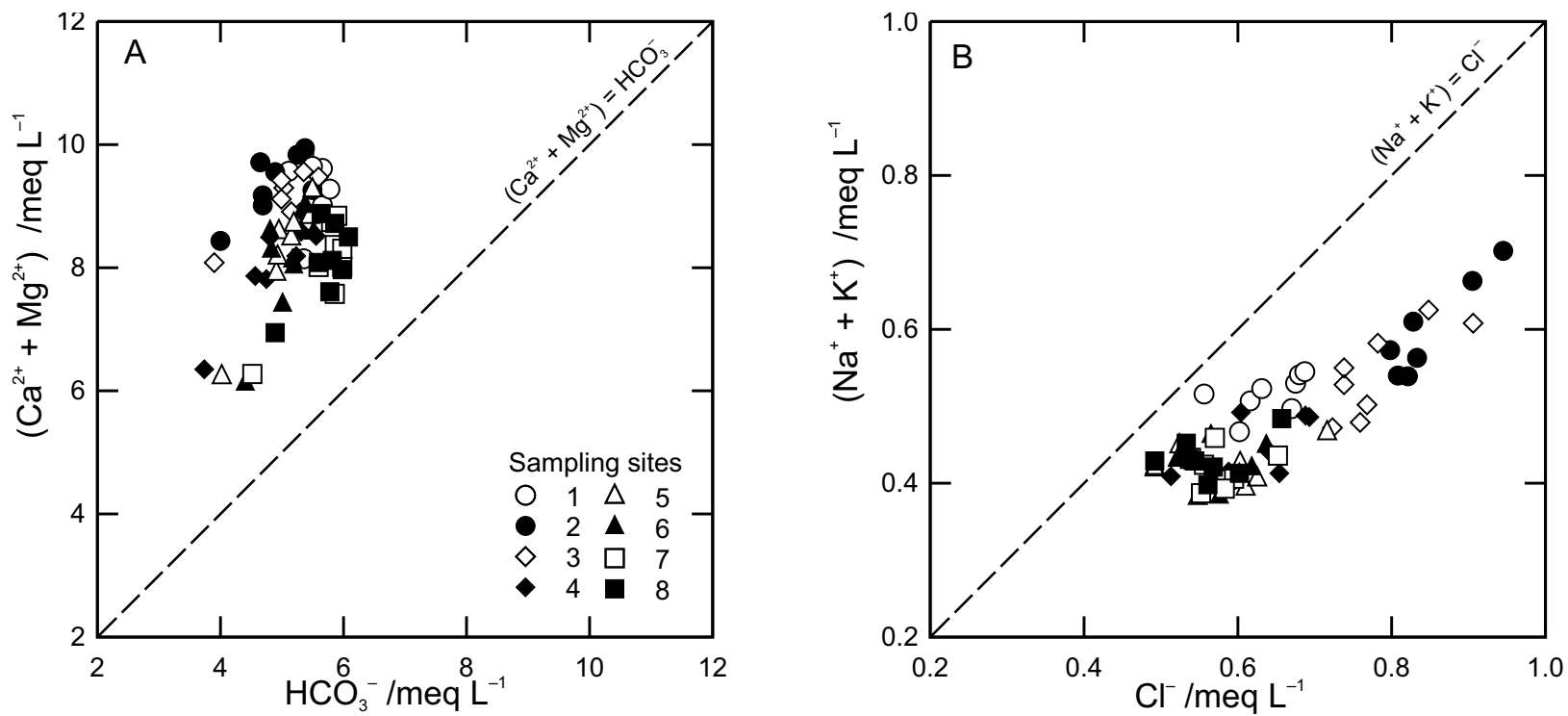

Figure 6. (A) $\mathrm{Ca} 2+$ plus Mg2+ plotted against $\mathrm{HCO} 3-$ concentrations (expressed in meq $\mathrm{L}-1$ ) of the Wiesent River. The dashed line indicates the stoichiometric relation of carbonate weathering. (B) $\mathrm{Na}+$ plus $\mathrm{K}+$ plotted against $\mathrm{Cl}$ - concentrations (expressed in meq $L-1)$. The dashed line indicates the stoichiometric relationship for salt dissolution. 